\title{
THE USE OF MICROFINANCE TO MITIGATE FINANCIAL EXCLUSION
}

\section{Abstract}

Objective: The problem of financial exclusion is closely correlated to the development of the financial market, also in the regional aspect. In less developed countries ignored by commercial financial institutions, the only chance for the community lies with local financial institutions focused on the implementation of social goals. These can be, for example, microfinance institutions focused on serving poor and socially excluded people. Currently, microfinance institutions run their operations all over the world, in the richest countries and in poor ones. The aim of this article is to define and present the problem of financial exclusion and to examine microfinance as a way of mitigating the problem. Microfinance helps to mitigate financial exclusion, enabling social inclusion for many people via financial products tailored to their needs.

Research Design \& Methods: The research offers conclusions based on analysis of data and reports published by microfinance institutions and deductive and inductive reasoning.

Findings: The research results show that financial inclusion plays a vital role in economic development and poverty alleviation. In order to improve access and usage of banking products, it is also necessary to increase financial awareness and knowledge. MFIs should strive to achieve social goals.

Implications/Recommendations: Microfinance institutions all over the world should strive to achieve social goals through a wide range of microfinance products, and not only through microcredit. In order to increase the impact of microfinance institutions and achieve social goals, a scenario for the functioning of MFIs was proposed. This scenario assumes co-implementation of social and commercial goals, which is a condition of retaining the idea of microfinance.

Przemysław Pluskota, University of Szczecin, Faculty of Economics, Finance and Management, Mickiewicza 64, 71-101 Szczecin, Poland, e-mail: przemyslaw.pluskota@usz.edu.pl, ORCID: https://orcid.org/0000-0001-7951-065X.

This is an open access article distributed under the terms of the Creative Commons Attribution-NonCommercial-NoDerivatives 4.0 License (CC BY-NC-ND 4.0); https://creativecommons.org/ licenses/by-nc-nd/4.0/. 
Contribution: The article presents the proposed model of microfinance activity which takes into account social goals and the digitisation of activities.

Keywords: financial exclusion, microfinance institutions, microfinance, poverty. JEL Classification: D14, G21, G23, I32.

\section{Introduction}

According to World Bank data, half of the global adult population does not have access to financial services. The worst situation is found in developing countries. Very often, financial exclusion is related to poverty, which is a serious problem in Africa and South and Southeast Asia in particular.

The issue of financial exclusion is connected with financial market development and is correlated to the overall development level of any given region. In less developed regions ignored by commercial financial institutions, the only chance for the community lies with local financial institutions focused on the implementation of social goals. An example of such activity is microfinance, which gained popularity thanks to Muhammad Yunus and his Grameen Bank initiative. Currently, microfinance institutions run their operations all over the world, in the richest countries and in poor ones.

The aim of this article is to define and present the problem of financial exclusion and to examine microfinance as a way of mitigating the problem. The following hypothesis has been formulated: "microfinance and microfinance institutions mitigate the problem of financial exclusion". The analytical part of the article is preceded by a literature review and presentation of the relevant research results.

\section{The Concept and Extent of Financial Exclusion}

According to the dictionary definition, the term "exclude" means "to prevent or restrict the entrance of; to bar from participation, consideration, or inclusion; to expel or bar especially from a place or position previously occupied". This is the general meaning of the term, and it refers to all aspects of functioning, regarding both individuals and economic entities. Still, it reflects the main idea of exclusion as a phenomenon, i.e. expelling a person from a group to which the person previously belonged.

Financial exclusion is most often defined as a process in which individuals encounter obstacles in accessing financial services in order to meet their needs, which prevents them from functioning properly within society (Financial Services Provision... 2008). Iwanicz-Drozdowska et al. (2009), 
citing Anderloni, Braga and Carluccio (2007), define exclusion as encountering difficulties in using any financial services that are necessary for everyday functioning in society, and those affected are usually low-income people and people with low social standing. The organisations of microfinance institutions such as the Microfinance Centre (MFC), European Microfinance Network (EMN) and Community Development Finance Association (CDFA) define financial exclusion as lack of access to appropriate forms of indispensable financial services not only for individuals and households, but also for groups of people and microenterprises (From Exclusion to Inclusion...2007, p. 12). The causes of the lack of access to basic financial services most often include high costs of access, low income or no income, lack of acceptable security, no credit history or insufficient credit history, and high costs of contract enforcement (Diriker, Landoni \& Benaglio 2018, p. 9).

Very often, financial exclusion was equated with the problem of the geographical accessibility of financial services, being the result of the closure of bank branches. In line with the development of research studies related to this problem, the definition has also evolved to include difficulties in accessing all kinds of financial services (loans, savings, insurance) as well as modern payment services. In the late 1990s, the definition of "financial exclusion" was expanded to cover individuals' limited access to major financial services (Financial Services Provision... 2008, p. 9). Financial exclusion is considered to be part of a much broader problem: social exclusion, which affects some groups of people who do not have access to basic services such as a workplace, a place to live, education and healthcare (Fila 2018, p. 534).

The academic literature describes at least two approaches to defining the financial exclusion phenomenon (Anderloni, Braga \& Carluccio 2007, pp. 7-8). The first approach is broad and focuses on financial needs and impediments to using financial services by low-income individuals of low social standing. Such financial services include having a bank account and the possibility of making cashless payments, access to loans at a "reasonable" interest rate, and the possibility of making some (even if small) savings. Moreover, low-income individuals should have access to appropriate life, health, and property insurance. The second approach is more restrictive and emphasises access to more specific services that do not affect the household budget, but at the same time constitute an important element of an individual's life, survival, security, and participation in social and economic life. 
The reason for financial exclusion in developing countries is most often poverty, whereas in developed countries it is the excessive indebtedness of households, which is an effect of falling into a debt spiral as a result of recklessly taking out loans, losing one's job, a business failure, or - mainly in the case of the homeless - lack of ID documents or a fixed address (Gostomski 2009, p. 314). The reason may also be a limited range of bank branches, when it is not possible to access the bank account online. An available, efficient, and reliable financial infrastructure decreases the cost of financial intermediary services, making financial products and services available to a greater number of citizens. Financial inclusion is connected with the development of (both stationary and mobile) financial infrastructure, based on modern technological solutions, and the institutional and legal environment (Ardic, Imboden \& Latortue 2013, p. 36).

Apart from the above-mentioned impediments, there are also financial and non-financial barriers (Beck, Demirgüç-Kunt \& Martinez Peria 2008, pp. 398-99). The former include: bank fees, the cost of operating a bank account, and the requirement to deposit a certain amount of money in the account. The non-financial barriers most often include the need to present a complete set of specific documents.

Examining the problem of financial exclusion, the European Commission distinguished (Financial Services Provision... 2008, pp. 11-14):

- banking exclusion - individuals' wages, salaries, old age or disability pensions or other benefits are not transferred into their bank accounts, they have no possibility of making savings in a bank account or transactions via a bank account, they cannot avail themselves of electronic forms of contact with the bank or basic transaction services,

- savings exclusion - lack of funds to enable saving, no habit of saving, no contacts with banks due to limited trust in banks,

- credit exclusion - no contracted loans, no credit cards, overdue payments, no creditworthiness, declared bankruptcy,

- insurance exclusion - no life or property insurance policies taken out.

Some research studies show a wider range of financial exclusion, including access to pension and investment products, at the same time differentiating between products for individuals and for business entities (Financial Inclusion 2013, p. 15). According to Adamek (2010), financial exclusion should be examined together with social exclusion and poverty, as these phenomena may be the cause and result of one another. Access to and use of basic services rendered by financial entities operating in the mainstream financial sector may be (and are) a decisive factor in social integration, self- 
-esteem, family and social relationships, and the possibility of employment. On the other hand, social alienation determined by various factors, e.g. unemployment, low income, poverty, low education level, discrimination on the basis of gender or race, is directly mirrored in the range of access to and consumption of, among others, financial services. Social exclusion means a lack of opportunity for individuals to participate in various aspects of life, marginalisation in the area of employment and income, few possibilities to participate in social networks and decision-making processes, and a low quality of life. Other factors affecting social exclusion include: gender, age, place of residence, ethnic identity, and immigrant status (Fila 2013, p. 27). There are also interactions between financial exclusion and poverty. Summing up, financial exclusion is closely related to social exclusion and poverty, and is not limited to any specific region or country - like the two latter phenomena, financial exclusion is a global problem (Adamek 2010, pp. 17-20).

There are 2.5 billion adults around the world who don't have access to a bank account. However, the level of financial exclusion is diversified (Figure 1). The Middle East and Sub-Saharan Africa are the regions where the situation is the worst, whereas the highest numbers of adult bank account holders can be found in developed countries. This clearly shows the dividing line between developed and developing countries.

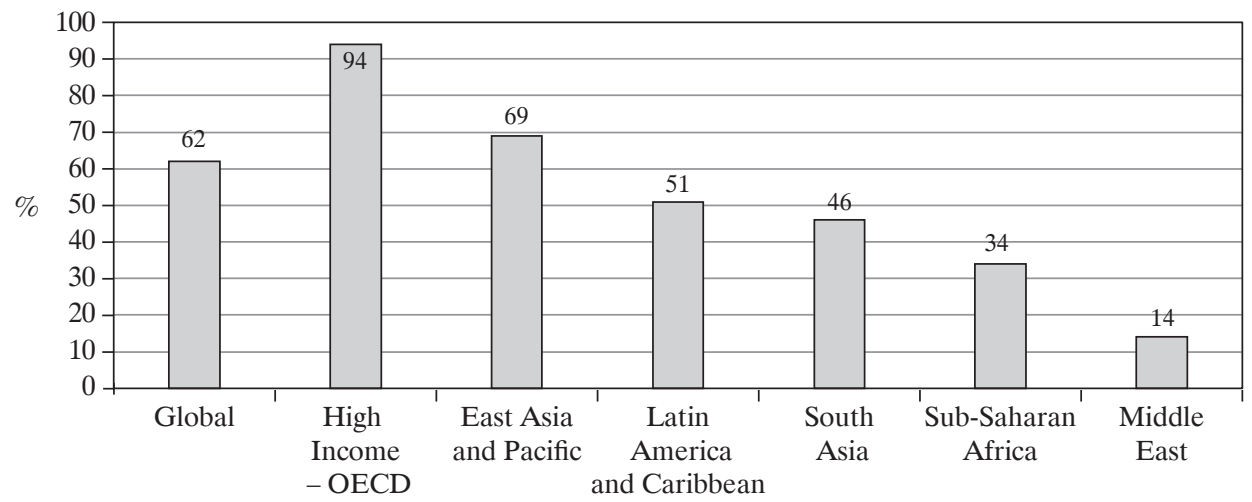

Fig. 1. Percentage of Adults with Bank Accounts

Source: Patwardhan, Singleton \& Schmitz (2018, p. 11).

There are many factors that contribute to the process of reducing financial exclusion, but the most important one is financial education 
(Maison 2013, p. 200), which should start with employees of financial institutions, as only then will they be able to ensure services of value to the customer. The level of financial knowledge among customers should also be increased, as it will help them to move about the world of finance more efficiently. Individuals with a higher level of economic knowledge are more likely to avail themselves of various financial offers and products that facilitate everyday life.

A concept closely related to financial exclusion is financial inclusion, which consists in including business entities in the group of users of financial services. It is a multi-dimensional concept that is reflected in a wide range of financial products, starting with payments and savings, though loans and insurance policies, to pensions and investment products (Financial Inclusion 2013, p. 15). Making use of financial services and accessing them is also conditioned by various factors affecting the extent to which indispensable financial products are used.

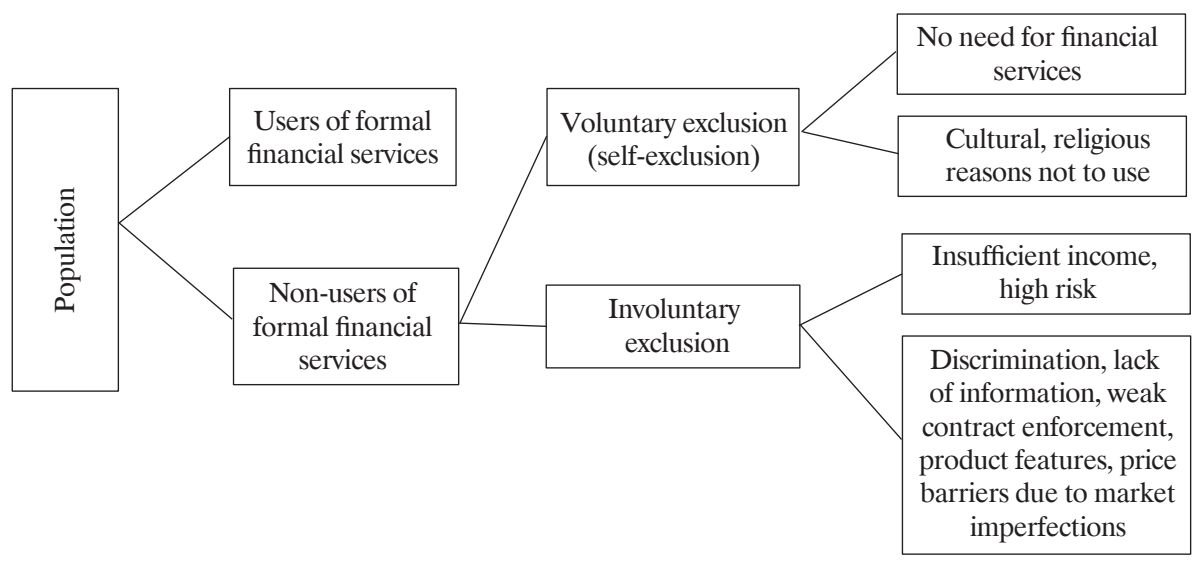

Fig. 2. Use of and Access to Financial Services

Source: Financial Inclusion (2013, p. 16).

When determining financial inclusion, it is necessary to distinguish between making use of financial services and having access to them (Financial Inclusion 2013, p. 16; Financial Services Provision... 2008, p. 14). Some individuals have access to financial services, yet exclude themselves from the financial market. Others have indirect access via the possibility of using somebody else's account. There are also those who do not use financial services due to high risks, insufficient income, price barriers, no possibility of enforcing contractual conditions, or market imperfections (Figure 2). 
Financial inclusion makes it possible to gain advantage over excluded persons, making use of opportunities such as investment in education, saving for one's future pension, securing oneself against risks. However, not all financial products are appropriate for everyone. This in particular refers to loans involving a risk of excessive indebtedness. Therefore, financial inclusion should not mean making use of a bank product (loan) at any cost.

The problem of financial exclusion is very important from the point of view of the economic growth of a country or region. There is a positive correlation between financial system development and GDP (Beck, Demirgüç-Kunt \& Levine 2004, p. 29; Financial Inclusion 2013, p. 44). The most important conclusion that can be derived from this study is the moderate to strong correlation between the extent of financial product usage and GDP per capita in individual countries (Chaia et al. 2009, pp. 7-8) ${ }^{1}$. This shows that it is possible to increase the level of financial integration (i.e. mitigate financial exclusion) by establishing an effective regulatory system, effective legal environments, and favourable conditions for financial inclusion.

The correlation between economic development and access to financial services is also confirmed by Beck, Demirgüç-Kunt and Martinez Peria $(2008)^{2}$. According to them, any minimum balance required to open a bank account, bank fees for operating a bank account, the number of documents required to open an account, minimum amounts of loans (taken out for consumption or business purposes), the number of days required to prepare a loan application - all these factors are negatively correlated to GDP per capita, whereas the number of places where it is possible to submit a loan application, being an indicator of lower barriers that restrict access to loans, is positively and significantly correlated to GDP per capita. Factors such as fees for granting loans to consumers and businesses, the cost of international bank transfers, fees for using ATMs, and the availability of places where deposit accounts may be opened, are not significantly correlated to the economic and financial development of a given country (Beck, Demirgüç-Kunt \& Martinez Peria 2008, p. 415).

Thus, financial system development, defined as the increased availability of financial services, makes it possible to effectively alleviate poverty and to reduce its level in society, which may have a positive effect on the life of the poorest.

${ }^{1}$ The GDP per capita of 94 countries (out of 102 included in the study).

${ }^{2}$ In the years 2004-2005, they examined 5 major banks in 115 countries. 


\section{Financial Exclusion and Poverty in the European Union}

Over the past five years, financial exclusion and poverty in the European Union have been decreasing. According to Eurostat data, in 2017 nearly 113 million people (22.5\% of the population) were at risk of poverty or social exclusion (Table 1). This group includes people with incomes below the poverty line adopted in the various countries, who are at risk of poverty due to their living conditions or affected by persistent material deprivation ${ }^{3}$.

The greatest decrease in poverty (by $11 \%$ of the population) since 2008 was found in Poland, where the number of people at risk of poverty fell to ca. 7.3 million, which means a decrease of 4 million people. The greatest increase was recorded in Greece (by 6.7\%), which was a consequence of the financial crisis (Figure 3). As analysis of the percentage of the population at risk of poverty shows that the worst situation in this regard is in Bulgaria (38.9\%), Romania (35.7\%), and Greece (34.8\%), where more than one third of society is at risk of poverty. The opposite is the case in the Czech Republic $(12.2 \%)$, Finland $(15.7 \%)$, and Slovakia $(16.3 \%)$.

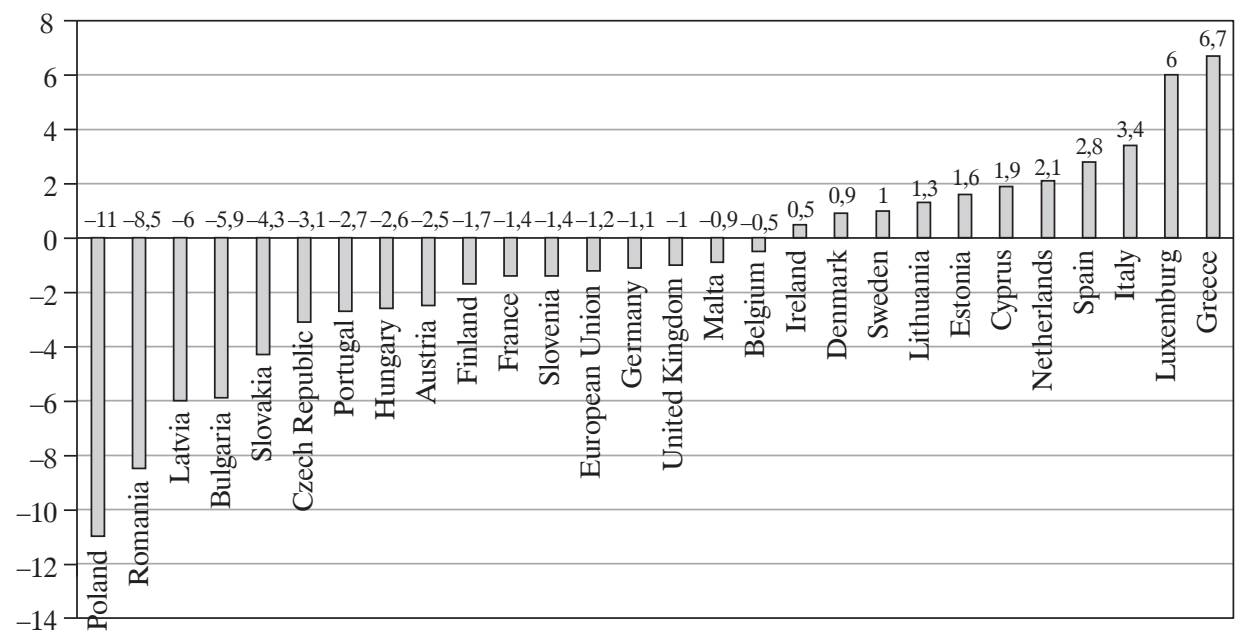

Fig. 3. Change in the Risk of Poverty and Social Exclusion in the European Union in 2017 Compared to 2008

Source: Downward Trend... (2018).

${ }^{3}$ Persons affected by persistent material deprivation are those who are not able to pay their utility bills, who have paid work for less than one fifth of a year, and who cannot afford a one-week annual holiday away from home. 
Table 1. People at Risk of Poverty or Social Exclusion in the EU in 2008 and 2017

\begin{tabular}{|c|c|c|c|c|}
\hline \multirow{2}{*}{ Country } & \multicolumn{2}{|c|}{$\%$ of total population } & \multicolumn{2}{|c|}{ In thousands } \\
\hline & 2008 & 2017 & 2008 & 2017 \\
\hline European Union* & 23.7 & 22.5 & 116,070 & 112,917 \\
\hline Belgium & 20.8 & 20.3 & 2,194 & 2,296 \\
\hline Bulgaria & 44.8 & 38.9 & 3,421 & 2,767 \\
\hline Czech Republic & 15.3 & 12.2 & 1,566 & 1,167 \\
\hline Denmark & 16.3 & 17.2 & 887 & 980 \\
\hline Germany & 20.1 & 19.0 & 16,345 & 15,516 \\
\hline Estonia & 21.8 & 23.4 & 291 & 305 \\
\hline Ireland & 23.7 & 24.2 & 1,050 & 1,135 \\
\hline Greece & 28.1 & 34.8 & 3,046 & 3,702 \\
\hline Spain & 23.8 & 26.6 & 10,786 & 12,236 \\
\hline France & 18.5 & 17.1 & 11,150 & 10,771 \\
\hline Croatia** & - & 27.9 & - & 1,159 \\
\hline Italy & 25.5 & 28.9 & 15,082 & 17,407 \\
\hline Cyprus & 23.3 & 25.2 & 181 & 215 \\
\hline Latvia & 34.2 & 28.2 & 740 & 544 \\
\hline Lithuania & 28.3 & 29.6 & 910 & 843 \\
\hline Luxemburg & 15.5 & 21.5 & 72 & 126 \\
\hline Hungary & 28.2 & 25.2 & 2,794 & 2,465 \\
\hline Malta & 20.1 & 19.2 & 81 & 83 \\
\hline Netherlands & 14.9 & 17.0 & 2,432 & 2,864 \\
\hline Austria & 20.6 & 18.1 & 1,699 & 1,563 \\
\hline Poland & 30.5 & 19.5 & 11,491 & 7,273 \\
\hline Portugal & 26.0 & 23.3 & 2,757 & 2,399 \\
\hline Romania & 44.2 & 35.7 & 9,115 & 7,040 \\
\hline Slovenia & 18.5 & 17.1 & 361 & 345 \\
\hline Slovakia & 20.6 & 16.3 & 1,111 & 856 \\
\hline Finland & 17.4 & 15.7 & 910 & 849 \\
\hline Sweden & 16.7 & 17.7 & 1,528 & 1,765 \\
\hline United Kingdom** & 23.2 & 22.2 & 14,069 & 14,359 \\
\hline Iceland & 11.8 & $12.2^{\mathrm{p}}$ & 36 & $40^{\mathrm{p}}$ \\
\hline Norway & 15.0 & 16.1 & 701 & 841 \\
\hline Switzerland & 18.1 & 17.8 & 1,333 & 1,460 \\
\hline
\end{tabular}

* data for 2008 exclude Croatia, data for 2017 are estimates; ** 2016 instead of 2017; $\mathrm{p}$ - provisional data.

Source: Eurostat, http://appsso.eurostat.ec.europa.eu (accessed: 12 January 2019). 


\section{The Idea and Significance of Microfinance}

Increasing the availability of financial services makes it possible to effectively fight poverty and reduce its level in society, which may have a positive effect on the life of the poorest. One of the major tasks is therefore to establish institutions that are willing to serve low-income individuals who, despite having considerably smaller financial resources and needing significantly lower loan amounts, are able to pay much more for the loan than customers in developed countries. Due to lack of credit history, lack of loan security, and financial status, the commercial banking sector is not interested in cooperating with this group of customers. On the other hand, the poorest are unable to accept the commercial conditions of cooperation.

The solution to increasing the availability of basic financial services is microfinance - a recognised tool for fighting social and financial exclusion as well as poverty in the world. This view is shared by the European Commission, which has promoted microfinance as an effective tool for fighting these problems, and by Armendariz de Aghion and Morduch (2009), who consider microfinance to be a tool for supporting social transformations.

Microfinance is associated with financial services for poor or low-income people, and involves institutions that grant small, unsecured loans, often on the principle of group liability, along with obligatory savings. Microfinance is also defined as the tools to offer the poor basic access to financial services in the form of loans, savings, money transfers, and microinsurance. However, nowadays microfinance also includes services aimed at improving the living conditions of the poorest - programmes that improve health care, education and training, and support social enterprises. The target groups can break the vicious circle of poverty thanks to microfinance offers that are tailored to their needs.

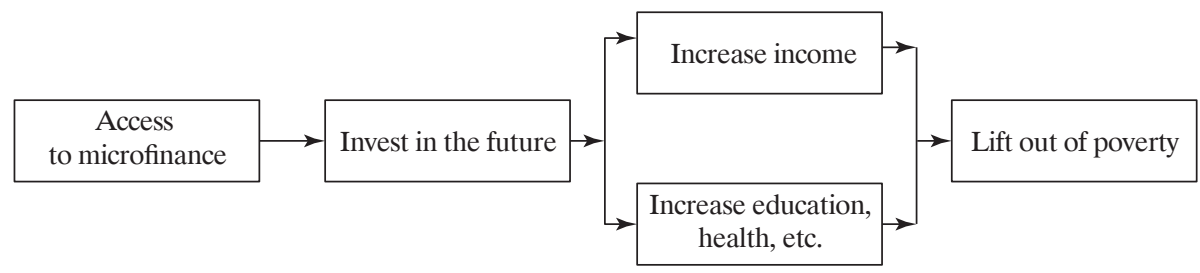

Fig. 4. A Simple Causal Chain from Micro-credit and Micro-savings to Poverty Alleviation

Source: Stewart et al. (2010, p. 39). 
According to Alińska (2008), the clients of microfinance customers are individuals from diversified social and occupational groups. It is virtually impossible to indicate a specific range of potential customers representative of the demand. Moreover, this would not make sense, as it depends on numerous elements and phenomena that take place in the economy on the national, regional, and local levels. Indicating uniform categories in relation to the whole microfinance movement is also impossible due to the differences in the economic development across countries. Nevertheless, it is possible to identify several major categories of people who are to the greatest extent representative of the demand for microfinance services: the unemployed, individuals at risk of social exclusion and poverty, individuals who cannot or will not use the services of traditional financial institutions, women, young people at the start of their careers, immigrants, farmers and people living in rural areas, and the smallest business entities which have been functioning for a short period of time or are only just starting their activity.

At the end of 2017, there were 139 million customers of microfinance institutions ( $+5.6 \%$ compared to 2016$), 83 \%$ of whom were women; $62 \%$ of the borrowers were farmers. The portfolio value of the $981^{4}$ institutions amounted to USD 114 billion ( $+15.6 \%$ compared to 2016) (Microfinance Barometer 2018). In order to increase the range and strength of effect, microfinance institutions have, to an increasing extent, been using modern technologies to reach their potential customers and offer them their services. Also, most of them have been implementing alternative distribution channels (ATMs, mobile phones).

Microfinance has been developing and evolving not just in the poorest regions of the world. The microfinance movement is an important element of the financial market in the more developed countries too. This is because microloans are needed not only by people in Asia, Africa, and Latin America, but also by people in the EU. Microfinance products are likewise necessary in industrial and developing countries where commercial banks are not interested in performing small transactions (loans or deposits) for impoverished people. The customer profile of microfinance institutions looks different in wealthier countries, but the purpose remains the same regardless of a country's level of economic development: a better life for the borrower and their family. The target groups are also similar. MFIs focus their attention mainly on women, socially excluded individuals, the unemployed, and microenterprises. 
The institutions operating in the poorest countries and in those characterised by a higher level of social and economic development are quite diversified, both in terms of the form and scale of their business, and their market position. The differences are the result of divergent internal conditions, the most important of which are (Alińska 2008, pp. 177-78):

1. The scale of poverty as well as social and financial exclusion, which is shown by the share of the poor in the total population (the more people there are in this group, the greater the need for microfinance products).

2. The scale and form of social assistance received from the state, which reduces the readiness to take up new challenges and hinders entrepreneurial attitudes.

3. The willingness of entrepreneurs to start new businesses due to legal regulations, market capacity, and competition.

4. The attitudes and strategies adopted by traditional financial institutions, resulting mainly from the possibilities of financing higher-risk customers.

The diversity of microfinance is manifested by the wide spectrum of institutions falling into this category which offer microfinance products. In the European Union, microfinance services are offered by specialised institutions operating in the banking sector (cooperative, commercial, microfinance, and savings banks) and outside the banking industry (financial cooperatives, non-for-profit organisations, NGOs) (Diriker, Landoni \& Benaglio 2018). The institutions may also be classified from the point of view of target customer groups. Banks mainly serve start-ups and microenterprises, while non-banking institutions focus mainly on financially excluded individuals, even though there are exceptions (The Regulation of Microcredit in Europe... 2007, p. 9).

The data presented in Table 2 show not only the diversity of microfinance, but also the countries which are affected by poverty and financial exclusion. Microfinance institutions have the most clients in South Asia (India, Bangladesh, Vietnam), whereas the portfolios of the greatest value can be found in Latin America. The global microfinance sector is developing, as evidenced by the increase in the number of customers everywhere apart from Eastern Europe and Central Asia (the greatest increase in the number of customers was in the Middle East and in North Africa: $+11.4 \%$ ) as well as by the increase in the portfolio value (most significant in East Asia and the Pacific region: $+18.1 \%$ compared to 2016 ). 
Table 2. Top Ten Countries by Number of Borrowers

\begin{tabular}{|c|c|c|c|}
\hline Rank & Country & $\begin{array}{c}\text { Number of borrowers in } 2017 \\
\text { (mln USD) / change compared } \\
2016\end{array}$ & $\begin{array}{l}\text { Loan portfolio (bn USD) / } \\
\text { change compared } 2016\end{array}$ \\
\hline 1 & India & $50.9(+5.8 \%)$ & $17.1(+26.3 \%)$ \\
\hline 2 & Bangladesh & $25.6(+3.5 \%)$ & $7.8(+17.0 \%)$ \\
\hline 3 & Vietnam & $7.4(+2.8 \%)$ & $7.9(+18.9 \%)$ \\
\hline 4 & Mexico & $6.8(-3.8 \%)$ & $4.4(+5.5 \%)$ \\
\hline 5 & Philippines & $5.89(+16.3 \%)$ & $1.3(+17.5 \%)$ \\
\hline 6 & Pakistan & $5.7(+25.9 \%)$ & $1.8(+39.6 \%)$ \\
\hline 7 & Peru & $5.1(+9.5 \%)$ & $12.6(+17.0 \%)$ \\
\hline 8 & Brazil & $3.5(+1.1 \%)$ & $2.6(+2.7 \%)$ \\
\hline 9 & Colombia & $2.8(-0.7 \%)$ & $6.3(+5.6 \%)$ \\
\hline 10 & Cambodia & $2.4(-4.7 \%)$ & $8.1(+21.6 \%)$ \\
\hline
\end{tabular}

Source: Microfinance Barometer (2018).

In the European Union, microfinance business is most often run by NGOs (40\%) and non-bank financial institutions (29\%), and every fifth institution surveyed by the European Microfinance Network and Microfinance Centre runs its business on a financial cooperative basis. The purpose of microfinance institutions' operations in the European Union is mainly financial inclusion and job creation (Figure 5), and their main targets are low-income persons, the unemployed, young people, immigrants, and social welfare beneficiaries (Diriker, Landoni \& Benaglio 2018, p. 30). The main difference between MFIs operating in the EU and in less developed countries is the smaller share of women in the customer group. As for financial products, most of the analysed entities offer business loans (80\%), personal microloans (50\%), and loans for SMEs (37\%). The microfinance products that are gaining more and more popularity are substitution products such as microinsurance, microleasing, and mortgage loans. Among European entities there are two dominant types of microloans: business microloans granted to businesses and personal microloans granted to natural persons. Both products differ in terms of value (EUR 8,913 and EUR 3,098, respectively) and maturity (45 months vs 31 months). In 2017, nearly two-thirds of the microfinance institutions also offered non-financial products that were supplementary to their offer.

In 2017, European microfinance institutions had almost one million customers $(8 \%$ more than in the previous year), of whom ca. $30 \%$ were 
women. The institutions disbursed over 660 thousand microloans totalling more than EUR 2 billion (Table 3).

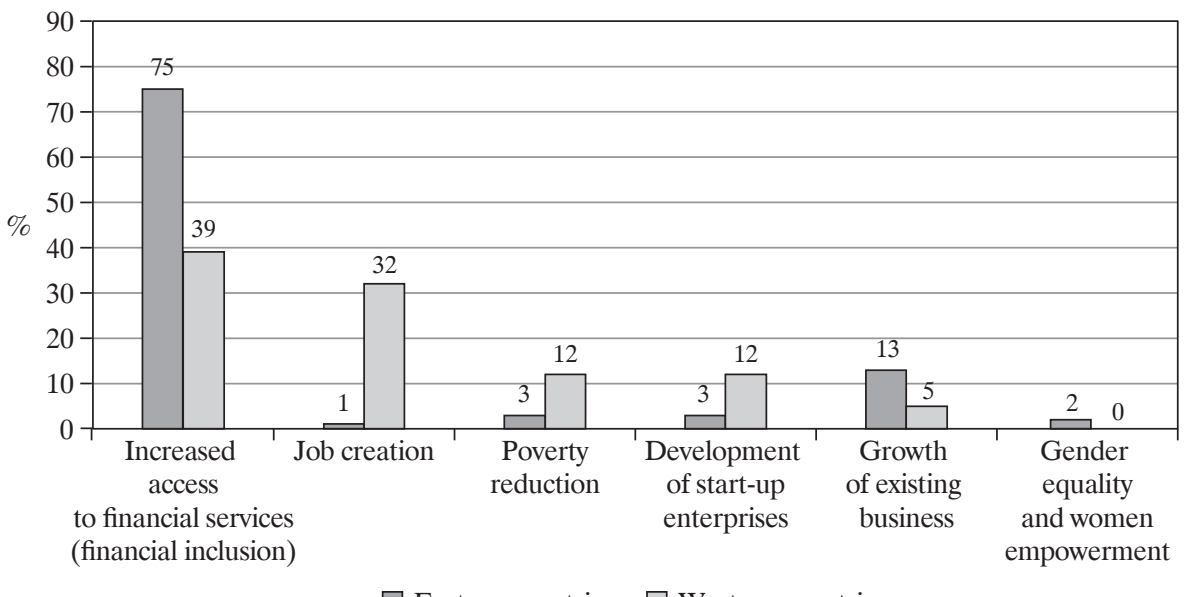

Eastern countries $\square$ Western countries

Fig. 5. Primary Mission of Microfinance Institutions by Region Source: Diriker, Landoni \& Benaglio (2018, p. 29).

The data presented in this study show the substantial diversity of microfinance institutions, both in terms of products and the institutions themselves. Microfinance entities also have other goals, but there is one goal shared by all of them: financial inclusion. Regardless of the size of the institution or its place of business, microfinance entities do their best to enable as many people as possible to have access to financial services, even the most basic ones that meet the fundamental needs. In parallel to financial integration, microfinance institutions offer education to the extent that it enables the rational and conscious use of financial products.

\section{Conclusion}

Compared to developed countries, developing countries encounter more problems with access to basic financial services. The research results have shown that financial inclusion plays a vital role in economic development and poverty alleviation. In order to improve access to and usage of banking products, it is also necessary to increase financial awareness and knowledge. A way to mitigate the issue is microfinance, which, according to Muhammad Yunus, makes it possible to handle the problems effectively. 


\begin{tabular}{|c|c|c|c|c|c|}
\hline $\begin{array}{l}\tilde{t} \\
\tilde{t}\end{array}$ & 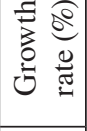 & $\cong$ & $\infty$ & $\infty$ & $\uparrow$ \\
\hline 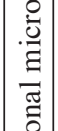 & $\hat{\bar{i}}$ & $\begin{array}{l}\text { I } \\
\underset{\text { N }}{\infty} \\
\text { in }\end{array}$ & $\begin{array}{l}\text { oे } \\
\text { बें }\end{array}$ & ฉे & $\begin{array}{l}\stackrel{2}{2} \\
\stackrel{+}{+} \\
\stackrel{n}{2}\end{array}$ \\
\hline 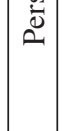 & $\stackrel{\circ}{\stackrel{\sim}{c}}$ & $\begin{array}{l}\underset{N}{\tilde{N}} \\
\stackrel{n}{n}\end{array}$ & 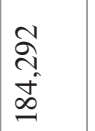 & $\widehat{\widehat{\Omega}}$ & $\begin{array}{l}\stackrel{0}{1} \\
\text { N } \\
\infty \\
\infty\end{array}$ \\
\hline $\begin{array}{l}\tilde{\Xi} \\
\tilde{\Xi}\end{array}$ & 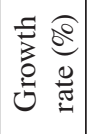 & n & in & 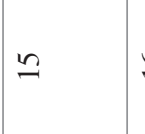 & 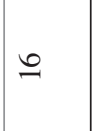 \\
\hline 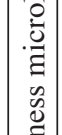 & $\hat{\stackrel{i}{~}}$ & 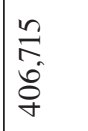 & 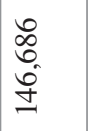 & $\underset{\mathbf{S}}{\mathrm{S}}$ & $\begin{array}{l} \pm \\
\tilde{n} \\
n \\
\infty \\
N\end{array}$ \\
\hline $\bar{\emptyset}$ & $\stackrel{\circ}{\stackrel{\nu}{\sim}}$ & 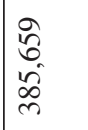 & $\begin{array}{l}\infty \\
0 \\
0 \\
0 \\
0 \\
0 \\
-\end{array}$ & ๙ૂ & 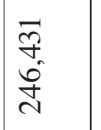 \\
\hline \multirow{3}{*}{ 褐 } & 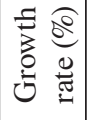 & $\infty$ & 0 & $=$ & $n$ \\
\hline & $\overline{\vec{i}}$ & $\begin{array}{l}\sqrt[r]{g} \\
\dot{g} \\
\infty \\
\infty \\
\infty\end{array}$ & 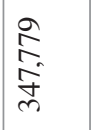 & $\begin{array}{l}\stackrel{R}{a} \\
\text { ì }\end{array}$ & $\begin{array}{l}0 \\
\text { ले } \\
\stackrel{0}{0}\end{array}$ \\
\hline & 윰 & $\begin{array}{l}\tilde{\Omega} \\
\hat{\jmath} \\
\sigma\end{array}$ & 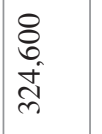 & $\begin{array}{l}\mathscr{\mathscr { D }} \\
\infty \\
-1\end{array}$ & $\begin{array}{l}\text { ले } \\
\text { ते } \\
\text { तु }\end{array}$ \\
\hline & 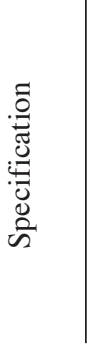 & 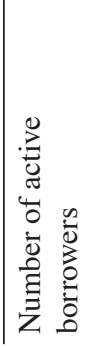 & 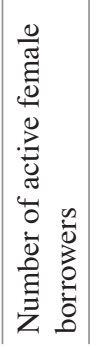 & 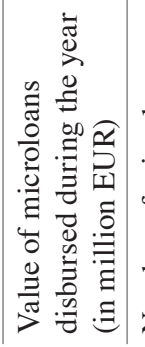 & 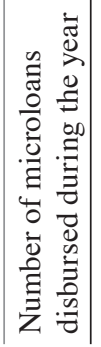 \\
\hline
\end{tabular}


Microfinance institutions all over the world should strive to achieve social goals through a wide range of microfinance products, not only through microcredit. Financial inclusion through microfinance is increased not only by means of microcredit, as nowadays microfinance is equated with a wide range of products, not only financial products, and also with much-needed financial education. Informed use of financial services will avoid many of the problems associated with excessive debt (Grazioli et al. 2020). However, financial inclusion does not mean credit for all at any price. This is a challenge that the microfinance industry faces in times of economic hardship. Digital financial solutions can leverage the business of MFIs and increase the range of their activity, also in financial inclusion. Modern solutions should be used by all MFIs. However, the range and level of those solutions should depend on the region, customers, and the macroeconomic environment. The new model requires collaboration between MFIs and the banking sector (including the central bank), the government, and other capital donors, which can have an impact on improving the financial capability of MFIs and financial inclusion. However, financial profits ought not to be the primary goal. They should cover operating costs and be oriented towards achieving social goals. All participants of the financial market will benefit from such an approach.

In order to increase the impact of microfinance institutions and achieve social goals, a scenario for the functioning of MFIs was proposed (Figure 6). This scenario assumes co-implementation of social and commercial goals, which is a condition of retaining the idea of microfinance. In the mixed model, capital may be sourced from public funds and from donors, but also from the financial market (optionally) or commercial microfinance institutions. However, the main source of capital is the funding provided by public institutions, and the objective of such an entities is to provide help to the most impoverished people. This may be the reason why external commercial investors show little interest in this model. There is a risk that any entities that intend to continue their microfinance operations will strive towards commercialisation, which will lead to the implementation of the commercial scenario. However, the possibility of implementing social goals, which helps to establish and nurture a positive image, should incline the commercial sector to fund entities of this type. This model appears to be the most viable one, as it is able to meet the expectations of both the public sector and, in part, the private sector, and at the same time bring many benefits. 


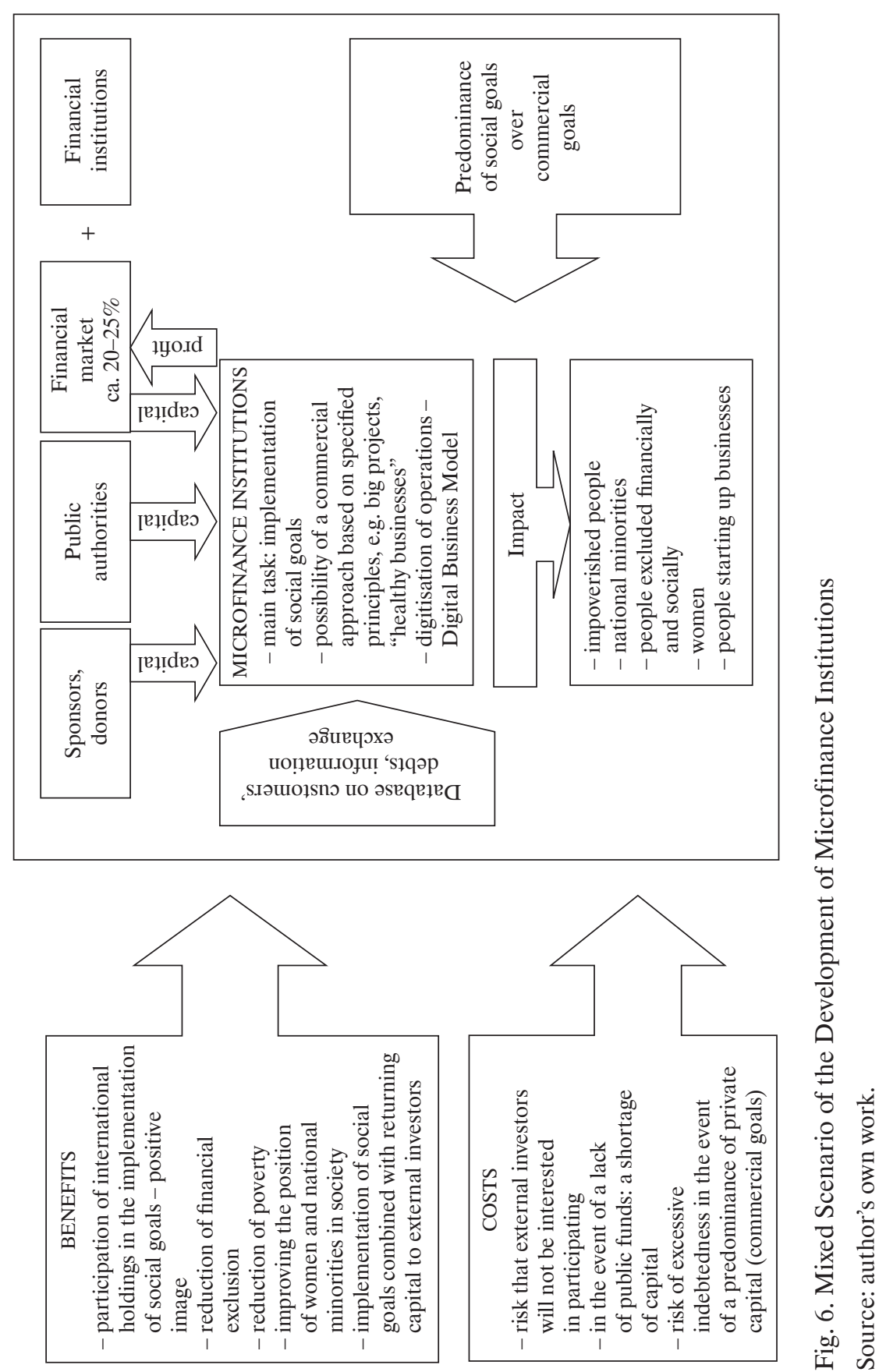


Thanks to microfinance, financial inclusion is increased not only via microloans, as nowadays microfinance encompasses a wide range of financial products which are accompanied by essential financial education. The conscious use of financial products will help avoid many of the problems related to excessive indebtedness. Modern technological solutions can increase the availability of financial products to society, but this process will be hindered without appropriate knowledge. If financial inclusion is to have positive results, it must be promoted in a responsible manner. Financial integration will not mean loans for anybody and at any cost.

\section{Bibliography}

Adamek, J. (2010) Mikrofinanse islamskie - zatożenia, produkty, praktyka. Warszawa: CeDeWu.

Alińska, A. (2008) Instytucje mikrofinansowe w lokalnym rozwoju spoteczno-gospodarczym. Warszawa: Szkoła Główna Handlowa w Warszawie.

Anderloni, L., Braga, M. and Carluccio, E. (2007) New Frontiers in Banking Services. Emerging Needs and Tailored Products for Untapped Markets. Berlin-Heidelberg-New York: Springer.

Ardic, O. P., Imboden, K. and Latortue, A. (2013) Financial Access 2012. Getting to a More Comprehensive Picture. Washington: CGAP and International Finance Corporation.

Armendariz de Aghion, B. and Morduch, J. (2009) Ekonomia mikrofinansów. Gdańsk: Wydawnictwo AnWero.

Beck, T., Demirgüç-Kunt, A. and Levine, R. (2004) Finance, Inequality and Poverty: Cross Country Evidence. National Bureau of Economic Research Working Paper 10979, https://doi.org/10.3386/w10979.

Beck, T., Demirgüç-Kunt, A. and Martinez Peria, M. S. (2008) "Banking Services for Everyone? Barriers to Bank Access and Use around the World". The World Bank Economic Review 22(3): 397-430, https://doi.org/10.1093/wber/lhn020.

Chaia, A., Dalal, A., Goland, T., Gonzalez, M. J., Morduch, J. and Schiff, R. (2009) "Half the World is Unbanked". Financial Access Initiative, www. financialaccess.org (accessed: 26 January 2019).

Diriker, D., Landoni, P., Benaglio, N. (2018) "Microfinance in Europe: Survey Report 2016-2017”. European Microfinance Network, Microfinance Centre.

Downward Trend in the Share of Persons at Risk of Poverty or Social Exclusion in the UE (2018), Eurostat.

Fila, J. (2013) "Innowacyjność mikrofinansów - dylematy i wyzwania dla systemu finansowego". Studia Ekonomiczne 173: 26-35.

Fila, J. (2018) "Microfinance Institutions in Poland - towards Preventing Social and Financial Exclusion". Economic and Environmental Studies, Vol. 18, No. 2(46), 531-49, https://doi.org/10.25167/ees.2018.46.4.

Financial Inclusion (2013). Global Financial Development Report 2014. The World Bank. 
Financial Services Provision and Prevention of Financial Exclusion (2008). European Commission VC/2006/-183.

From Exclusion to Inclusion through Microfinance (2007). Report 1 - Social and Financial Exclusion Map. Microfinance Centre, European Microfinance Network, Community Development Finance Association.

Gostomski, E. (2009) "Znaczenie mikrofinansów w wybranych krajach" in E. Ostrowska, J. Ostrowski (eds) Rynki finansowe. Mikrofinanse. Sopot: Fundacja na rzecz polskich związków kredytowych - Instytut Stefczyka.

Grazioli, R., Pizzo, G., Poletti, L., Tagliavini, G. and Timpano, F. (2020) The Social Return on Investment (SROI) of Four Microfinance Projects. European Investment Fund Working Paper 65.

Iwanicz-Drozdowska, M., Matuszczyk, A., Nowak, A. and Kitala, R. (2009) Produkty finansowe i edukacja finansowa w Polsce na tle wybranych krajów wysoko rozwiniętych. Raport z badań, 04/S/0010/08. Warszawa: Szkoła Główna Handlowa w Warszawie.

Maison, D. (2013) Polak w świecie finansów. Warszawa: Wydawnictwo Naukowe PWN.

Microfinance Barometer (2018), 9th Edition, https://www.convergences.org/en/104906-2/ (accessed: 15 January 2019).

Stewart, R., Van Rooyen, C., Dickson, K., Majoro, M. and De Wet, T. (2010) What Is the Impact of Microfinance on Poor People? A Systematic Review of Evidence from Sub-Saharan Africa 2010, Technical Report. London: EPPI-Centre, Social Science Research Unit, University of London.

The Regulation of Microcredit in Europe. Expert Group Report (2007). European Commission, https://ec.europa.eu/docsroom/documents/3669/attachments/1/translations/ en/renditions/pdf (accessed: 15 December 2018). 